\section{Wrong site for Japanese labs}

SIR - David Swinbanks' article on the relocation of a Japanese laboratory ( $\mathrm{Na}$ ture 358, 703; 1992) mentioned my name but did not explain my stance and the background to the local and national protests. Allow me to explain the reasons why the location and experiments of Japan's National Institute of Health (NIH) in a densely populated residential area have been criticized by the mass media and public opinion in Japan.

The NIH is Japan's largest biotechnology and pathogen laboratory, with seven P3-laboratories and a large laboratoryanimal facility with thousands of animals; it also uses organic solvents and large amounts of radioisotopes. The new NIH laboratory's seven-storey building (on a small $2,000-\mathrm{m}^{2}$ site) is immediately adjacent to houses, two welfare facilities for handicapped people, a major hospital and Waseda University with 40,000 students. So the NIH is a densely concentrated laboratory in one of the most densely populated areas in the world.

Since 1987, many residents have strongly opposed the transfer of the NIH to the new site. But in 1988, the NIH arrogantly started construction, backed by riot police. Although a lawsuit against the government has not yet been adjudicated, the NIH has recently moved to the new site and started experiments. We are, of course, still asking it to halt the experiments and to move to another, unpopulated site.

We contend that such a densely populated area is the wrong site for such a laboratory, because no biotechnology facility can be entirely safe. Furthermore, unknown genetically modified pathogens included in exhaust air from the laboratory are too dangerous, not only for the nearby residents but also for the population of Tokyo.

The rooftop vents of the NIH's seven P-3 laboratories, lab-animal facility and radioisotope laboratories are only 20 metres from houses and other neighbouring buildings. The NIH argues that it can set up such laboratories anywhere irrespective of environmental and population conditions and that the exhaust from the rooftop vents is clean and safe. If that is the case, why doesn't the NIH recycle the exhaust into the institute and let the staff themselves breathe it? The truth is, of course, that even the highly efficient filters cannot always catch all viruses in the exhaust from the P3-laboratory, and there is no safety standard yet for leaked recombinant DNA, tumour viruses and radioisotopes. The World Health Organisation's Laboratory Biosafety Manual (Geneva, 1983) states: "The exhaust air from the laboratory should be discharged directly to the outside or the buildings exhaust system so that it is dispersed away from occupied buildings and air intakes" ( $\mathrm{p}$. 26, emphasis added). But just outside the NIH are tens of thousands of residents.

The hitherto accepted guidelines for biotechnological experiments have referred only to laboratory conditions, not to the neighbouring environment. However, concerned governments have begun to pay attention to environmental aspects of laboratories. The Directive on the Contained Use of Genetically Modified Micro-organisms (23 April 1990) from the Council of the European Communities, reads:

The precise nature and scale of risks associated with genetically modified micro-organisms are not yet fully known and the risk involved must be assessed case by case;

It may be considered appropriate to consult the public on the contained use of genetically modified micro-organisms;

The user shall carry out a prior assessment of the contained uses as regards the risks to human health and the environment that they may incur." (Official Journal of the European Communities, No L 177, 8 May 1990.)

The NIH should apply the regulations proposed by the WHO and the EC to biotechnology laboratories in Japan and a comprehensive environmental impact assessment should be carried out.

If local residents were to be infected with genetically modified pathogens from the NIH, infection might spread not only to Tokyo but all over the world. Thus we are campaigning not only for Japanese but also for humankind as a whole.

\section{Shingo Shibata}

(Chairman, Plaintiffs of Lawsuit

against Japan's $\mathrm{NIH}$ ),

1-18-6 Toyama, Shinjukuku,

Tokyo 162, Japan

\section{Gene therapy}

SIR - David Dickson reported recently (Nature 361, 387; 1992) on the approval by British authorities of the country's first gene therapy experiment, involving the transplantation of a functioning adenosine deaminase (ADA) gene into the bone marrow cells of a child suffering from ADA deficiency. In citing previous experiments carried out in the United States and Italy, Dickson writes that "in those cases, only T-cells were altered and the process had to be repeated at regular intervals". As the British protocol will involve manipulation of stem cells as well as $\mathrm{T}$ cells, these experiments may instead "result in one of the first permanent implantations of a manipulated human gene".

The report is incorrect. The ADAdeficiency gene therapy clinical trial currently under way in Italy is based on retroviral vector-mediated transduction of both peripheral blood lymphocytes and bone marrow cells, according to a protocol approved by the Italian National Ethical Committee and by the Ethical Committee of the San Raffaele Research Institute in Milano, where the trial is being carried out in collaboration with the Pediatric Clinic of the University of Brescia. Nature correctly reported on this trial shortly after its beginning ("Italians first to use stem cells", by Alison Abbott, 356, 465; 1992), by mentioning that it is based on the use of two vectors, differing in one base pair, for the two tissues. This would, it is hoped, allow monitoring of the circulating ADApositive T-lymphocytes and determine whether they derive from lymphocyte infection or from progenitor cells infected in the bone marrow. Furthermore, a Dutch research group headed by Dinko Valerio received approval in February 1992 for gene therapy of ADA deficiency by infection of bone marrow cells, although by a quite different protocol and this too was reported in Nature (355, 190; 1992).

\section{Fulvio Mavilio}

\section{Claudio Bordignon}

Instituto Scientifico San Raffaele,

Via Olgettina, 60, 20132 Milano, Italy

\section{Hard physics}

SIR - Readers of your article "Can quantum theory be understood?" ( $\mathrm{Na}$ ture 361,493 ; 1993) may be interested to learn of a new research project set up to investigate A-level students' conceptions of quantum physics. Despite the fact that it is 70 years since concepts such as 'wave-particle duality' were first formulated, no significant research on students' understanding of such conceptually unusual topics has been carried out.

Many A-level physics students do experience considerable difficulties in understanding the quantum physics section of the syllabus. The study will address the following questions. How can student understanding be identified? What patterns are found in student understanding? What implications have these patterns for learning? How can effective teaching be achieved?

I would be most interested in your readers' reactions.

Azam Mashhadi

Department of Educational Studies, University of Oxford,

15 Norham Gardens, Oxford OX2 6PY, UK 